\title{
New Possibilities of Supporting Polish SMEs within the Jeremie Initiative Managed by BGK
}

\author{
Ph.D. Damian Walczak \\ Faculty of Economic Sciences and Management, \\ Nicolas Copernicus University in Torun, Poland \\ Email:dwalczak@umk.pl \\ Ph.D. Grazyna Voss \\ Torun School of Banking, Poland \\ Email: gvoss@wp.pl
}

\section{Doi:10.5901/mjss.2013.v4n9p759}

\begin{abstract}
In developed countries small and medium-sized enterprises constitute a dominating group of entities, if considered by number, and are seen as the driving force of the economy. In 2011 in Poland 1,748,000 enterprises conducted business activity and out of that number $99.8 \%$ were businesses representing the SMEs sector $(1,781,000)$. These enterprises employed over 6.3 million people out of the total labour force amounting to 9 million and annually they generate approximately $50 \%$ of GDP. Due to the role played by the SMEs sector, it is important to protect that sector in the time of the economic slowdown. For that reason in 2012 Bank Gospodarstwa Krajowego (BGK), which is controlled by the Treasury, launched programmes aimed at supporting major social investments as well as some other programmes concerning collateral loan and credit programmes for SMEs. The programmes are intended to sustain employment in the sector. The objective of the paper is to present the areas of financial support for entities from the SMEs sector provided by means of the BGK budget funds.
\end{abstract}

Keywords: SME sector, state aid, JEREMIE, Bank Gospodarstwa Krajowego

\section{Introduction}

Small and medium-sized enterprises constitute one of the major driving factors of the social and economic development of the state. They stimulate its growth. For that reason the state undertakes a series of activities intended to support their development through, for instance, limiting barriers to growth, providing or stimulating developmental factors, or through counteracting negative determinants and strengthening constructive factors.

This support is especially useful considering the fact that entities representing the SME sector most frequently are owned by families and, as a matter of fact, it is hard to separate the assets that are owned by the family from the assets that belong to the enterprise. Liquidating an enterprise may result in the appearance of financial problems affecting all family members (European Commission, 2009). However, these companies should be treated differently since, as pointed out by Tagiuri and Davis (1996) '... organizational features of family firms account for both their strengths and their weaknesses'. Undoubtedly, on the one hand, they adjust quicker to the changing conditions, however, on the other hand, they are closed to the absorption of new knowledge and employing new labour from outside (Chrisman, Chua, Steier, 2011).

Relevant activities undertaken and targeted adequately by the state and its agencies may be helpful in encouraging entrepreneurship and supporting the development of enterprises, in particular in the time of a crisis. No doubt these are the duties that the state should be held responsible for (Henry, 2010; Fan, 2003). However, a lot of activities undertaken by the state are frequently incidental, uncorrelated, not embedded in one current and result from short-term plans prepared by different ministries. One of the scarce forms of supporting entrepreneurship are the activities conducted by Bank Gospodarstwa Krajowego (BGK), which is $100 \%$ controlled by the State Treasury.

The objective of the paper is to present the areas of financial support given to SMEs and financed with the BGK budget within the JEREMIE initiative. 


\section{The SMEs sector in Poland}

In accordance with the ruling of the European Commission, Poland applies the following three categories conditioning the determination of company size: 'micro', 'small' and 'medium'. The three categories include the annual average number of employees, the annual turnover and the balance sum (see Table 1).

Table 1. The criteria applied for classifying companies as 'micro', 'small' and 'medium' sized'

\begin{tabular}{|c|c|c|c|}
\hline $\begin{array}{c}\text { The company } \\
\text { category }\end{array}$ & $\begin{array}{c}\text { The annual average } \\
\text { number of employees }\end{array}$ & The annual turnover & The balance sum \\
\hline Micro & $<10$ & $\leq 2 \mathrm{mln}$ euro & $\leq 2 \mathrm{mln}$ euro \\
\hline Small & $<50$ & $\leq 10 \mathrm{mln}$ euro & $\leq 10 \mathrm{mln}$ euro \\
\hline Medium & $<250$ & $\leq 50 \mathrm{mln}$ euro & $\leq 43 \mathrm{mln}$ euro \\
\hline
\end{tabular}

Source: Commission Regulation, 2008.

Companies representing the SMEs sector constitute approximately $99.8 \%$ of the total number of companies operating in Poland. For instance, in 2011 out of the total of 1,784,603 operating entities merely 3,189 were classified as 'big'. Companies of the SMEs sector employed 6.3 million people out of the total of 9.0 million of labour employed in the private sector. However, the worldwide financial crisis commenced in 2008 has had a negative impact on the functioning of those companies in Poland. In 2008 in Poland there were 1.86 million entities in the SMEs sector which employed 6.62 million people, while in 2011 that number fell to 1.78 million with 6.33 million employees (see Table 2).

Table 2. The number of companies and the number of employees classified by their legal forms

\begin{tabular}{|c|c|c|c|c|c|}
\hline \multirow{2}{*}{ Year } & \multirow{2}{*}{ Total } & \multicolumn{3}{|c|}{ SMEs } & \multirow{2}{*}{ big } \\
\cline { 2 - 5 } & & micro & small & medium & \multirow{2}{*}{} \\
\cline { 2 - 5 } & \multicolumn{5}{|c|}{ The number of companies } \\
\hline 2006 & 1714915 & 1652998 & 44228 & 14708 & 2981 \\
\hline 2007 & 1777076 & 1713194 & 45184 & 15452 & 3246 \\
\hline 2008 & 1862462 & 1787909 & 54974 & 16327 & 3252 \\
\hline 2009 & 1673527 & 1604417 & 50189 & 15808 & 3113 \\
\hline 2010 & 1726663 & 1655064 & 52591 & 15841 & 3167 \\
\hline 2011 & 1784603 & 1710598 & 54999 & 15817 & 3189 \\
\hline & \multicolumn{5}{|c|}{ The number of employees } \\
\hline 2006 & 8556132 & 3474574 & 976451 & 1542386 & 2562721 \\
\hline 2007 & 8969302 & 3592817 & 1007453 & 1619286 & 2749746 \\
\hline 2008 & 9494002 & 3727242 & 1194999 & 1698165 & 2873623 \\
\hline 2009 & 8829934 & 3464201 & 1123287 & 1643384 & 2599062 \\
\hline 2010 & 8859053 & 3399096 & 1143458 & 1649103 & 2667396 \\
\hline 2011 & 9028536 & 3508557 & 1181565 & 1646415 & 2691999 \\
\hline
\end{tabular}

Sources: GUS, 2013; GUS, 2012; GUS, 2011; GUS, 2010; GUS, 2009; GUS, 2008.

The SMEs sector in Poland generates almost 50\% of the GDP, and out of that, for instance, in 2011 micro companies generated 29.6\%, small companies 7.7\%, and medium companies 10.4\% (big companies 24.0\%; other entities 16.5\%, and revenues from customs duties and taxes generated 11.9\%) (PARP, 2012). Both the participation of the sector in GDP and the value of its production output (see Table 3 ) indicate its significance in the Polish economy. It is worth noting that both in the case of the number of enterprises, the number of employees (see Table 2), as well as in the case the production output the economic downturn in the SMEs sector occurred in 2009.

${ }^{1}$ The conditions for classifying an entrepreneur into an appropriate category are liable to conjunction. The major preliminary criterion for determining the category of a company is the annual average level of employment. However, as regards the levels of the annual turnover or the total annual balance sum in the SME sector, it is sufficient to select only one of them. 
Table 3. The production output and the participation of the SMEs sector in GDP

\begin{tabular}{|c|c|c|}
\hline Year & $\begin{array}{c}\text { The production output in } \\
\text { millions of PLN }\end{array}$ & $\begin{array}{c}\text { The participation of the } \\
\text { SMEs sector in GDP }\end{array}$ \\
\hline 2006 & 1140061 & $47.8 \%$ \\
\hline 2007 & 1280670 & $47.3 \%$ \\
\hline 2008 & 1416239 & $47.2 \%$ \\
\hline 2009 & 1335310 & $48.4 \%$ \\
\hline 2010 & 1396924 & $47.6 \%$ \\
\hline 2011 & 1523549 & $47.7 \%$ \\
\hline
\end{tabular}

Source: GUS, 2013; GUS, 2012; GUS, 2011; GUS, 2010; GUS, 2009; GUS, 2008; PARP 2012.

The economic slowdown that took place in Poland in the years 2009-2001 and again in 2012 confirms the values of the growth of GDP and of the unemployment level. In 2009 GDP rose by $1.6 \%$ which is a substantial change, if compared with 2008 (5.1\%). Unfortunately, after a relatively good year, as regards the growth of GDP in 2011, it rose again, however, the rise was very slight. The trend on the labour market needs to be emphasized. The worsening of the business cycle noted in 2009 automatically changed into an increase in the unemployment level, and its improvement noted in the years 2010-2011 only limited that dynamic increase in the unemployment. Also, such market behaviours oblige the government to develop plans supporting Polish enterprises.

Table 4. The dynamics of Gross Domestic Product seasonally unbalanced (average annual prices from the previous year) and the unemployment rate (registered unemployment) in the years 2006-2012

\begin{tabular}{|l|c|c|c|c|c|c|c|}
\hline Specification & 2006 & 2007 & 2008 & 2009 & 2010 & 2011 & 2012 \\
\hline GDP & 106.2 & 106.8 & 105.1 & 101.6 & 103.9 & 104.5 & 101.9 \\
\hline Unemployment rate (\%) & 14.8 & 11.2 & 9.5 & 12.1 & 12.4 & 12.5 & 13.4 \\
\hline
\end{tabular}

Source: GUS 2013a; GUS 2013b.

In many countries SMEs play a crucial role, however, in Poland this role is smaller, if compared with other European countries. In 2011 Poland had 36.2 SMEs per 1,000 of inhabitants, whereas in such countries as, for instance, the Czech Republic, Malta, and Portugal that rate was twice higher (see figure 1).

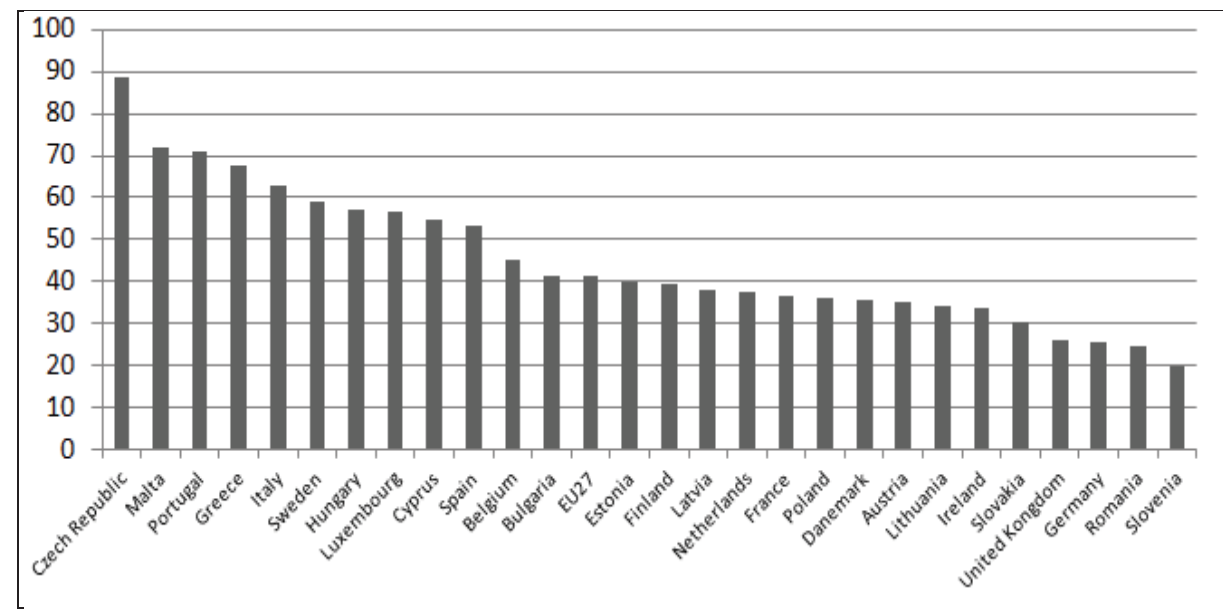

Figure 1. Number of SMEs (non-financial business economy) per 1,000 inhabitants in 2011 (Source: elaborated by the author based on the data derived from ECORYS, 2012; Eurostat 2013) 
Especially under unfavourable market conditions it is necessary to identify the factors which impede the functioning of enterprises. Liquidating such barriers may contribute to stopping the unfavourable situation related to the liquidation of economic entities or to decreasing the number of jobs offered by them. We can distinguish the activities both within the social and economic governance relative to the improvement of the so-called framework conditions in the functioning of enterprises as well as the intervention in the course of economic processes understood broadly as financial support. Obviously, each of the indicated barriers in the development of SMEs shown in Figure 1 is important, however, the financial barrier is one of the most significant impediments in the development of any company (Bartlett and Bukvič, 2011; Doern, 2009). Therefore, a further part of the present paper is focused on one of the activities of the Bank Gospodarstwa Krajowego targeted at limiting/liquidating such a serious impediment as capital gap (BIS, 2012)².

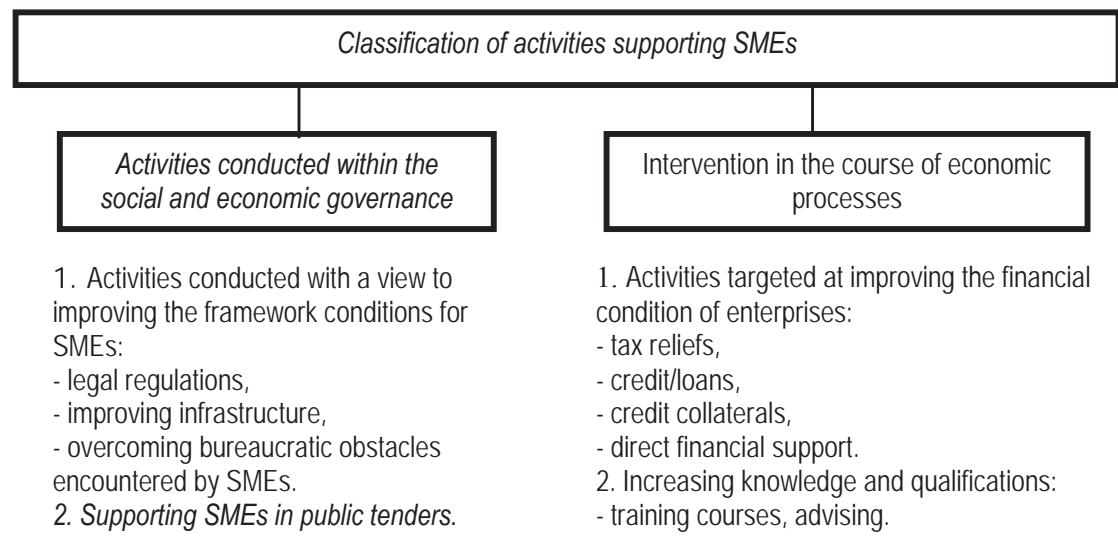

Figure 2. Methods of supporting SMEs (Source: Schuttenbach, 2000)

\section{The support of Bank Gospodarstwa Krajowego given to SMEs - the JEREMIE initiative}

Bank Gospodarstwa Krajowego, the only bank that is under $100 \%$ control of the State Treasury in Poland ${ }^{3}$, realizes the common mechanisms set out for the SMEs sector and recommended by the European Commission, including the JEREMIE (Joint European Resources for Micro-to-Medium Enterprises) initiative. This initiative consists in providing nonsubsidized support to micro, small and medium companies and is intended to finance their investments (Michalski, 2008). In Poland the JEREMIE initiative is not financed with additional EU funds, but with the funds coming from the regional operational programmes for the years 2007-2013 destined for developing entrepreneurship. Poland is the only country among the new EU member states that has decided to implement the programme at the regional level.

In the period of programming for the years 2007-2013 BGK has had the function of the manager ${ }^{4}$ of seven trust funds within the JEREMIE initiative which altogether managed to gather 1,764.35 million PLN (within specific regional programmes separate activities were considered in which this instrument is being implemented):

- Dolnoslaski Trust Fund valued at 405.73 million PLN (Activity: supporting revolving financial instruments applied by SMEs),

- Lodzki Regional Trust Fund valued at 188.63 million PLN (Activity: developing business environment),

- Pomorski Regional Trust Fund JEREMIE valued at 287.39 million PLN (Activity: non-adjustable financial instruments for SMEs),

- Wielkopolski Regional Trust Fund JEREMIE valued at 501.30 million PLN (Activity: developing a system of

${ }^{2} \mathrm{~A}$ mention should be made that during an economic crisis (economic slowdown) significant are activities taken independently, inside the company, and not only those initiated outside (Piatkowski, 2012).

${ }^{3}$ The major purpose of the activity of BGK is supporting the governmental social and economic programmes and the programmes for local governments and development including, in particular, the following projects: 1) realised with the use of means coming from the EU funds and from international financial institutions; 2) infrastructural; 3) related to the development of the SMEs sector, including ones realized with the use of public funds (The Act 2003).

${ }^{4} \mathrm{~A}$ manager's task is to initiate the repayable support given to Financial Intermediaries (loan funds, guarantees, banks and other financial institutions) and they, in turn, direct repayable financial instruments to SMEs. 
financial instruments of supporting entrepreneurship),

- Zachodniopomorski Regional Trust Fund JEREMIE valued at 280.00 million PLN (Activity: Advanced services of supporting enterprises),

- Kujawsko-Pomorski Regional Trust Fund JEREMIE valued at 39.8 million PLN (Activity: institutions in the business environment) and in effect from January 2013

- JEREMIE Trust Fund of the Mazowieckie province valued at 61.5 million PLN.

The JEREMIE initiative is addressed primarily to micro, small and medium enterprises which:

- have difficult access to external sources of financing (due to a low value of the possessed assets that may function as collateral),

- are at the stage of starting up their business activity (including graduates and persons who open up their businesses for the first time),

- have been operating on the market but do not have credit history (to present they have been using their own sources of financing and did not want or couldn't use external sources),

- do not possess collaterals of sufficient value.

The importance of the support in that area is best illustrated by the share of companies applying for a loan and the share of accepted loan applications. As indicated by the data provided by the National Bank in 2012, 21.6\% of companies applied for a loan, the rate of approved applications amounted to $83.6 \%$. According to the banking information, $62.0 \%$ of the disapproved loan applications resulted from not being creditworthy or from the lack of a collateral. The remaining 38.0\% resulted from independent causes (NBP, 2012; NBP 2013).

Table 5. The percentage of companies applying for a loan and the participation of approved loan applications in the years 2006-2012

\begin{tabular}{|l|l|l|l|l|l|l|l|}
\hline Specification & 2006 & 2007 & 2008 & 2009 & 2010 & 2011 & 2012 \\
\hline The percentage of companies applying for a loan & 31.4 & 32.4 & 27.4 & 25.1 & 23.2 & 21.9 & 21.6 \\
\hline The participation of approved loan applications & 87.7 & 86.9 & 81.4 & 80.8 & 83.3 & 89.9 & 83.6 \\
\hline
\end{tabular}

Source: NBP, 2013.

Firstly, within the JEREMIE initiative financial instruments are offered to intermediaries financing the activity of SMEs, for example:

a) Loan instruments:

- A global loan for loan funds,

- Credit line for banks and quasi-bank institutions.

b) Guarantee instruments:

- Guarantee for guarantee funds,

- Portfolio guarantee for banks and quasi-bank institutions.

c) Capital instruments:

- Capital support given to technology transfer funds, capital support given to 'mezzanine' funds.

Secondly, BGK also offers financial products to companies in the following forms (it must be emphasized that SMEs that are interested in using funds within the JEREMIE initiative do not apply directly to regional trust funds or to BGK. They use services of financial intermediaries, such as, for instance - banks, loan funds, Venture Capital funds):

a) guarantees,

b) credits/loans,

c) venture capital for financing development.

The non-subsidised character of the support shows that companies need to fulfil their obligations. That means that the major objective for BGK is not to subsidise the SMEs sector but provide it with financial means with a view to facilitating access to financial instruments adjusted to the needs of the sector. This approach is focused on micro and small enterprises being in the developmental stage which, hypothetically, would be deprived of the access to external financial means.

Another important role fulfilled by BGK is supporting the banking sector indirectly. The bank does not take customers from other banks but, actually, it enables them granting new loans and credits to enterprises which, without 
the guarantee support, would not be able to make use of that form of external capital.

Financial means which are returned to the Trust Fund by SMEs are used again for supporting Financial Intermediaries and in that way they reach entrepreneurs again. By the end of 2012 all funds had offered to entrepreneurs a total amount of 1.29 billion PLN and three of the funds as early as in August of 2012 had circulated the complete pool of money ${ }^{5}$ assigned for loans and guarantees to SMEs.

The benefits of the support offered by BGK include the following:

- increasing access for SMEs to external financing which is limited by the lack of credit history or property collaterals that are insufficient to borrow substantial amounts,

- conditions for financing SMEs (spreading instalments and other costs borne due to external financing),

- flexibility of financing (longer prolongation or payment periods),

- lowering loans/credit costs due to the lower risk of financing investments in progress.

\section{Concluding remarks}

The role of the SMEs sector in Poland is significant. SMEs employ over 6 million people and generate approximately $50 \%$ of GDP. Providing appropriate assistance is essential not only to the owners of SMEs (frequently whole families are engaged in running the business activity) but to the proper functioning of the whole economy. One of the supporting activities is the JEREMIE initiative coordinated by the Bank Gospodarstwa Krajowego whose purpose is to provide nonsubsidised support to micro, small and medium-sized enterprises. The financial products available within the initiative are destined to both financial intermediaries supporting the SMEs sector and entrepreneurs representing that sector. This initiative contributes not only to the development of enterprises and the creation of numerous work places but also encourages people not involved in doing business in setting up their own companies. The support offered, for instance, in the form of financial guarantees makes it possible to reduce the cost of capital by decreasing the risk taken by banks that finance a given investment and to maintain the credit rating at the same level and its possible use in a situation when the only way to obtain external capital is through a bank loan.

One of the merits of the JEREMIE initiative is its flexibility. Financial support may be given to start-ups or to companies with few assets, that is to companies that are not well-received by banks. Additional differentiation of the support given within the JEREMIE initiative in specific regional operational programmes allows the adjustment of activities to the territorial specificity.

In general, it may be mentioned that the JEREMIE programme does not consist only in providing financial support but also in providing support, however, to some extent only, in overcoming administrational and legal barriers. The procedures within that support programme are determined a priori and the ultimate beneficiary is informed about all his formal duties, already significantly simplified, at the very beginning of the process of applying for support. Some of these duties have even been shifted to the trust unit.

The importance of programmes similar to the JEREMIE programme will be increasing since the European Commission is, more or less officially, recommending that the European Union states after 2013 should assign for nonrepayable support, including loans, guarantees and financial support given to venture capital funds about $15 \%$ of the total sum received for the time period 2014-2020. Presently, the repayable form of support in Poland, as assessed by various institutions, amounts to about 2-3\% of the money that Poland has received for regional policy for the years 2007-2013.

\section{References}

Bartlett, W., Bukvič, V. (2001). Barriers to SME Growth in Slovenia. MOST: Economic Policy in Transitional Economies. 11(2). doi 10.1023/A:1012206414785.

BIS. (2012). SME Access to External Finance. BIS economics paper no. 16. January 2012.

Chrisman, J. J., Chua, J. H., Steier, L. (2011). Resilience of Family Firms: An Introduction. Entrepreneurship Theory and Practice. 35 (6), 1108-1111. doi: 10.1111/j.1540-6520.2011.00493.x.

Commission Regulation (EC) No 800/2008 of 6 August 2008 declaring certain categories of aid compatible with the common market in application of Articles 87 and 88 of the Treaty (General block exemption Regulation), Annex 1.

Doern, R. (2009). Investigating Barriers to SME Growth and Development in Transition Environments. A Critique and Suggestions for Developing the Methodology. International Small Business Journal. June 2009, 27(3). doi: 10.1177/0266242609102275.

ECORYS. (2012). EU SMEs in 2012: at the crossroads Annual report on small and medium-sized enterprises in the EU, 2011/12,

${ }^{5}$ From underlying financial means and, obviously, the funds are still spent on supporting SMEs. 
Rotterdam. Retrieved June 10, 2013, from Ecorys database.

European Commission. (2009). Final report of the expert group overview of family-business-relevant issues: research, networks, policy measures and existing studies, 8-13.

Eurostat. (2013). Demography - National data, 79. Retrieved June 7, 2013, from: http://epp.eurostat.ec.europa.eu.

Fan, Q. (2003). Importance of SMEs and the Role of Public Support in Promoting SME Development, World Bank. Retrieved May 7, 2013, from: http://worldbank.org.

GUS. (2008). Działalność przedsiębiorstw niefinansowych w 2007 r., Główny Urząd Statystyczny, Warszawa, 33-34.

GUS. (2009). Działalność przedsiębiorstw niefinansowych w 2007 r., Główny Urząd Statystyczny, Warszawa, 25-30.

GUS. (2010). Działalność przedsiębiorstw niefinansowych w 2008 r., Główny Urząd Statystyczny, Warszawa, 43-44.

GUS. (2011). Działalność przedsiębiorstw niefinansowych w 2009 r., Główny Urząd Statystyczny, Warszawa, 43-44.

GUS. (2012). Działalność przedsiębiorstw niefinansowych w 2010 r., Główny Urząd Statystyczny, Warszawa, 41-42.

GUS. (2013 a). Informacja Głównego Urzędu Statystycznego w sprawie zaktualizowanego szacunku PKB za lata 2011-2012, Główny Urząd Statystyczny, Warszawa.

GUS. (2013). Działalność przedsiębiorstw niefinansowych w 2011 r., Główny Urząd Statystyczny, Warszawa.

GUS. (2013b). Stopa bezrobocia w latach 1990-2013 (bezrobocie rejestrowane), Główny Urząd Statystyczny, Warszawa, 45.

Henry, C. (2010). SME policy and the role of government. Environment and planning c-government and policy. 28 (2), 191-194.

Michalski, G. (2008). Risk reduction in SME financing: Jeremie fund influence on financial situation of small and middle enterprises. In M. Cullik (Ed.), Rizeni a modelovani financnich rizik. Ostrava, 138-143.

NBP. (2012). Informacja o kondycji sektora przedsiębiorstw ze szczególnym uwzględnieniem stanu koniunktury w IV kw. 2011 oraz prognoz koniunktury na I kw. 2012, Narodowy Bank Polski, January 2012, 33. Retrieved June 19, 2013, from: http://www.nbp.pl.

NBP. (2013). Informacja o kondycji sektora przedsiębiorstw - dane źródłowe. Retrieved June 20, 2013, from: http://www.nbp.pl.

PARP. (2012). Raport o stanie sektora małych i średnich przedsiębiorstw w Polsce w latach 2010-2011, Polska Agencja Rozwoju Przedsiębiorczości, Warszawa, 19.

Piątkowski, M. (2012). Factors Strengthening the Competitive Position of SME Sector Enterprises: an Example for Poland. In M. Özşahin, C. Zehir (Ed.), Procedia: Social and Behavioral Sciences, vol. 58, Elsevier Ltd., United Kingdom 2012, 269-278.

Schuttenbach, L. (2000). Sektor małych i średnich przedsiębiorstw w Republice Federalnej Niemiec, Warszawa: PFPiRMiOEP, 57.

Tagiuri, R., \& Davis, J. (1996). Bivalent attributes of the family firm. Family Business Review, 9(2), 206. doi: 10.1111/j.17416248.1996.00199.x.

The Act on Bank Gospodarstwa Krajowego, passed in 14 March 2003 (Dz. U. Nr 65, poz. 594, z późn. zm.). 